(C) 2014

Ніщенко Т. М., аспірант

(науковий керівник - доктор економічних наук В. Я. Плаксієнко)

Полтавська державна аграрна академія

\title{
ОСОБЛИВОСТІ УПРАВЛІННЯ ПЕРСОНАЛОМ В АГРАРНОМУ ПІДПРИЕМСТВІ
}

\section{Рецензент - доктор економічних наук, професор Х. 3. Махмудов}

У статті обтрунтовано необхідність врахування сочіально-економічних та освітньо-кваліфікаційних факторів підвищення продуктивності праці з метою ефективного використання персоналу на підприємствах аграрної галузі. Розглянуто систему управління персоналом як складний механізм, між елементами якого існує тісний $і$ нерозривний взаємозв'язок. Наведено основні складові структури управління персоналом в аграрному підприємстві. Особлива увага звертається на забезпечення ефективної професійної віддачі висококваліфікованих прачівників.

Ключові слова: персонал, управління персоналом, аграрне підприємство, продуктивність npausi.

Постановка проблеми. На даному етапі розвитку сільське господарство України характеризується трансформаційними процесами, пов'язаними зі змінами форм господарювання, збільшенням частки підприємств, створенням принципово нових сільськогосподарських формувань. Переважна більшість підприємств аграрної галузі значно зменшила обсяги виробництва, змінила спеціалізацію, що обумовило потребу у сумісництві посад окремих спеціалістів та фахівців і загострило проблему ефективного використання наявного робочого персоналу. Загальновідомим є той факт, що побудова ефективної системи управління персоналом, достатня забезпеченість підприємства працівниками справляє позитивний вплив на основні економічні показники їх діяльності, такі як: продуктивність праці, прибуток, рентабельність тощо [2, с. 123].

Чимало науковців та управлінців шукає шляхи ефективнішої організації праці та управління нею задля досягнення найкращих результатів. Отже, управління персоналом $є$ однією 3 найважливіших сфер діяльності організації, що може багаторазово підвищити ефективність будьякого виробництва. Вивчення проблем ефективного управління персоналу аграрних підприємств обумовлено об'єктивними якісними змінами, що характеризують сучасну діяльність i трансформації в аграрному секторі, активну й визначальну роль людських ресурсів в управлінні підприємством [5, с. 9].
Аналіз останніх досліджень і публікацій, у яких започатковано розв'язання проблеми. Значний вклад у вивчення стану та розробки проблеми оцінки результатів діяльності управлінських працівників зробили такі відомі зарубіжні вчені як Г. Атаманчук, С. Болотов, Л. Горшкова, Р. Кюн, Х. Ріхтер, Р. Фатхутдінов та ін. Окремі аспекти дослідження механізмів підвищення ефективності управлінської діяльності на підприємстві стали об' єктом досліджень вітчизняних науковців, таких як П. Березівський, О. Бородіна, П. Гайдуцький, В. Герасимчук, О. Гудзинський, В. Данюк, Й. Завадський, І. Степаненко, В. Терещенко, В. Юрчишин та багато інших.

Автори в своїх роботах зазначають, що планування управління персоналом повинно здійснюватися у формі цільових комплексних програм відповідно до стратегії управління розвитком підприємства 3 обов'язковим врахуванням основних напрямів сучасної кадрової політики й демографічної ситуації, тенденцій науковотехнічного прогресу, оцінки персоналу та результатів його трудової діяльності, удосконалення роботи 3 персоналом [1, с. 235].

Однак, незважаючи на безумовну значимість проведених досліджень, система оцінки та механізм досягнення результативності діяльності управлінського персоналу підприємств аграрної сфери потребують глибшого дослідження та вдосконалення.

Процеси формування й використання управлінського персоналу в контексті забезпечення їх ефективності переважно розглядаються відокремлено, що не дає змоги здійснити об'єктивну оцінку роботи колективу, команди чи окремого керівника на основі співставлення результатів їх роботи 3 потенціалом, який був використаний.

Оцінка інтенсивності та характеру впливу соціально-економічних, технологічних й організаційних чинників на ефективність формування та використання персоналу на підприємствах аграрної галузі також потребує вдосконалення [3, c. 284].

Наразі $є$ передумови створення високоефекти- 


\section{СТОРІНКА МОЛОДОГО ВЧЕНОГО}

вного механізму реалізації персоналу у сфері аграрного виробництва. Однак для того, щоб задіяти такий механізм на практиці, необхідне його організаційне підкріплення у вигляді служб управління та розвитку персоналу.

Мета і завдання дослідження. Мета дослідження: теоретико-методичне обгрунтування й розробка пропозицій щодо формування особливостей удосконалення процесу формування управління персоналом в аграрному підприємстві та підвищення ефективності його використання.

Завдання дослідження: формування та дослідження особливостей процесу управління; розробка пропозицій щодо удосконалення даного процесу й підвищення ефективності використання персоналу.

Методи дослідження. 3 метою реалізації поставлених завдань застосовувалися такі методи дослідження як абстрактно-логічний, монографічний та метод формалізації.

Результати дослідження. Управління персоналом здійснюється в межах організаційних структур, через які реалізується планомірний i систематичний вплив на поведінку членів колективу організації та відносини між ними.
Ці структури мають сприяти цілеспрямованому й ефективному управлінню персоналом і всією організацією через механізм взаємодії принципів і засобів управління. Щодо сказаного вище влучно висловився Бенджамін Франклін: «Добре виконане завжди краще, ніж добре сказане» [7].

Кожне підприємство характеризується особливостями діяльності, ставить перед собою специфічні цілі, а кожен працівник має свої цінності й установки.

Крім того, зовнішнє середовище, в якому функціонують підприємства, постійно змінюється, як і показники, що характеризують його персонал.

Отже, доцільним є формування такої системи управління персоналом, яка враховувала б особливості діяльності саме аграрного підприємства [3].

Головна мета управління персоналом полягає в забезпеченні підприємства працівниками, які відповідають вимогам даного підприємства, а також їхньої професійної та соціальної адаптації.

Основними задачами, що їх вирішують структури з управління персоналом, вважаємо наступні дані (рис. 1):

Основні складові, структури управління персоналом в аграрному підприємстві

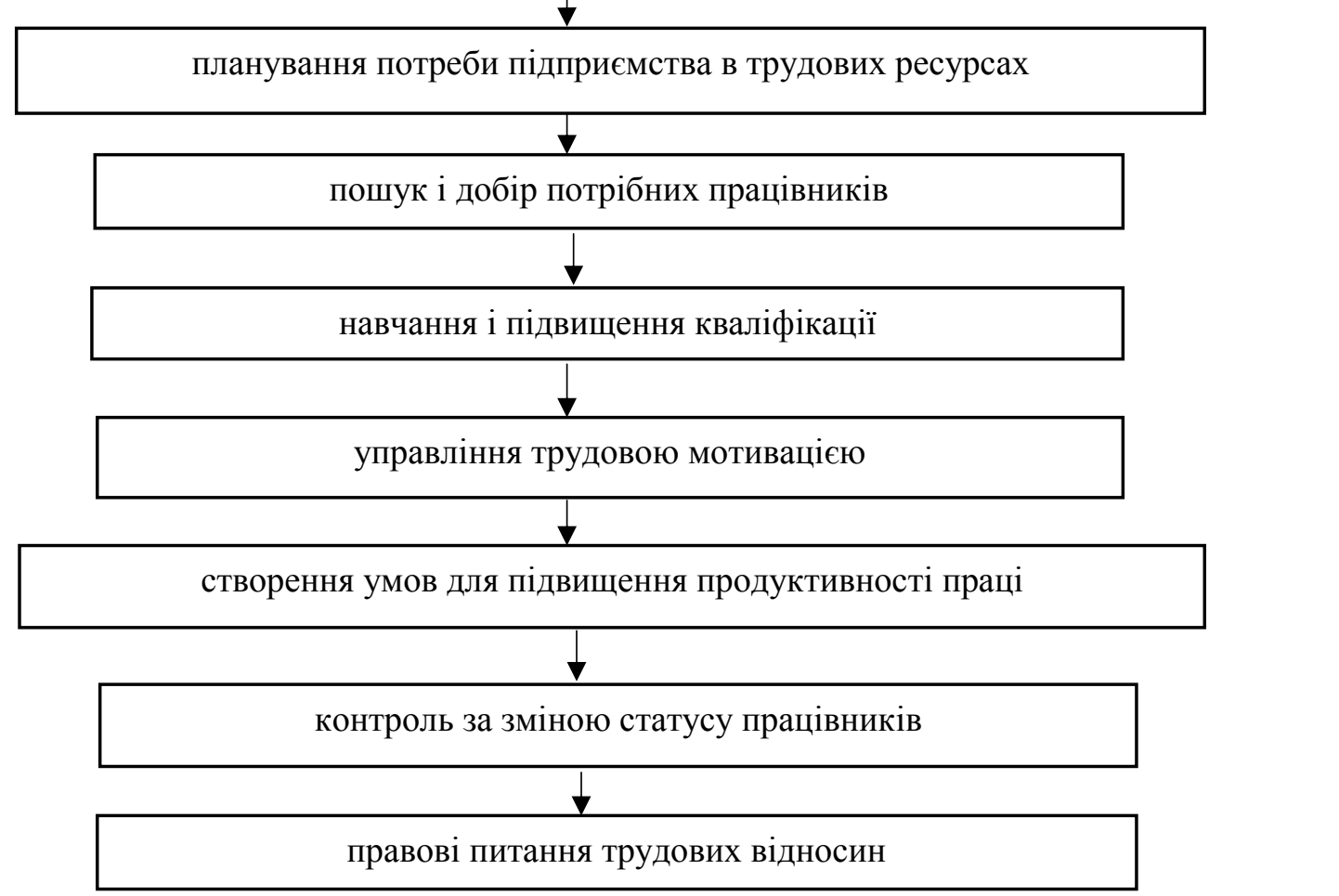

Рис. 1. Основні складові, структури управління персоналом на аграрному підприємстві [складено автором] 


\section{СТОРІНКА МОЛОДОГО ВЧЕНОГО}

Об'єднавши перші чотири складові структури управління персоналом, можемо зробити наступний висновок, що метою вирішення цих питань $\epsilon$ створення на кожному підприємстві системи навчання, підготовки та перепідготовки, направлення на додаткове навчання й підвищення кваліфікації, направлення на тренінги та семінари 3 урахуванням конкретних особливостей діяльності. Важливо зміцнювати зв'язки між базовими підприємствами та професорсько-викладацьким складом ВНЗ аграрного профілю й профільних науково-дослідних станцій. Це дає зримі переваги, зокрема:

- підприємства отримують можливість навчання своїх працівників на базі ВНЗ;

- навчальні заклади мають змогу направляти дипломованих випускників на роботу (стажування, проходження практики) до сільськогосподарських підприємств.

Отже, система навчання та підвищення кваліфікації на аграрних підприємствах складається 3 трьох основних напрямів (рис. 2).

Крім того ефективним кроком у напрямі вдосконалення знань, умінь і навичок працівників $\epsilon$ організація системи навчання безпосередньо на підприємстві. Це можуть бути додаткові навчальні семінари щодо ведення сільськогосподарсь- кого виробництва, які проводитимуть більш досвідчені працівники підприємства. У разі їх практичного впровадження матиме місце подвійна мотивація праці: задоволення потреби у визнанні, підвищення авторитетності досвідчених робітників, які мають відмінні результати праці, з одного боку, і прагнення нових працівників досягти трудових висот та отримати заохочення - 3 іншого.

Наступний напрям підвищення ефективності управління персоналом - нематеріальне стимулювання праці в рамках уосконалення ведення соціально-трудових відносин. За ієрархією А. Маслоу, матеріальні стимули здійснюють вплив на працівників до того часу, допоки не будуть задоволені базові потреби людини [8]. Наступний крок - задоволення потреб працівників у приналежності, визнанні, повазі з боку оточуючих та самореалізації. В даному випадку вступають у дію нематеріальні стимули праці. Оскільки інтереси людей постійно переплітаються, поєднуються, змінюються, то система стимулювання й мотивації праці на підприємстві повинна бути комплексною, системною та гнучкою, швидко адаптуючись до змін навколишнього середовища.

Управління системою навчання та підвищення кваліфікації в підприємстві аграрної галузі

\begin{tabular}{|c|c|}
\hline$\rightarrow$ & $\begin{array}{l}\text { Напрями реалізації: } \\
\text { - навчання майбутніх фахівців аграрної галузі на базі підприємства; } \\
\text { - проходження виробничої та переддипломної практик для студентів аграрних вузів }\end{array}$ \\
\hline & $\begin{array}{l}\text { Напрями реалізації: } \\
\text { - направлення працівників відповідного профілю до провідних підприємств галузі } \\
\text { для залучення інноваційного досвіду; } \\
\text { - участь у аграрних виставах; } \\
\text { - направлення працівників на різноманітні навчальні семінари }\end{array}$ \\
\hline & $\begin{array}{l}\text { Напрями реалізації: } \\
\text { - навчання та підвищення кваліфікації працівників підприємства у вузах аграрного } \\
\text { профілю; } \\
\text { - проходження курсів підвищення кваліфікації }\end{array}$ \\
\hline
\end{tabular}

Мета: забезпечення ефективної професійної віддачі висококваліфікованих працівників

Рис. 2. Управління системою навчання та підвищення кваліфікації в аграрному підприсмстві 


\section{СТОРІНКА МОЛОДОГО ВЧЕНОГО}

Важливою складовою особливості управління персоналом $є$ створення умов для підвищення продуктивності праці. Як вбачають окремі дослідники, зокрема К. Р. Макконнелл, С. Л. Брю, під продуктивністю праці розуміють середній іiі продукт праці чи виробіток одного працівника за одну годину [6, с. 780]. Іншими словами, це поняття характеризує відношення результату до витрат праці [6, с. 636]. Продуктивність праці важливий трудовий показник: від іiі рівня і динаміки залежить чисельність працівників, рівень і фонд оплати праці, обсяг виробництва продукції тощо.

Значна увага має приділятися управлінню кар'єрним ростом працівника. У працях В. Храмова рекомендується розробити ланцюжок кадрових переміщень у вигляді планування кадрового резерву та схеми заміщення посад. Кар'єрне зростання може відбуватися як у вертикальному напрямку (переміщення на більш високу посаду), так і в горизонтальному (підвищення кваліфікації, розширення функцій і завдань) та діагональному напрямках (зростання авторитету і визнання 3-поміж колег). Потреба працівників досліджуваних підприємств у визнанні може бути частково реалізована також за рахунок надання права участі у прийнятті організаційно-управлінських рішень та надання права підпису документів організаційного характеру.

Невід'ємною складовою ефективного управ-

\section{БІБЛІОГРАФІЯ}

1. Виноградський М. Д., Бєляєва С. В., Виноградська A. М. [та ін.]. Управління персоналом. Навч. пос. для ВНЗ. - К. : ЦУЛ. - 2006. - 500 с.

2. Дієсперов B. C. Сільськогосподарська праця в нових умовах / Дієсперов В. С. - К. : Інститут аграрної економіки УААН, 2009. - 184 с.

3. Кибанов А. Я. Управление персоналом: регламентация труда. - Учеб. пос. - 3-е изд., перераб. и доп. / А. Я. Кибанов, Г. А. Мамед-Заде, Т. А. Родкина. - М. : Экзамен, 2008. - 480 с.

4. Колот А. М. Мотивація персоналу : підручник [Текст] / А. М. Колот. - К. : КНЕУ, 2002. - ління персоналу була й залишається система оцінювання працівників. Головне її завдання полягає у «визначенні його трудового потенціалу, рівня використання цього потенціалу, відповідності працівника наявним вимогам до посади (професії), міри ефективності його трудової діяльності, а отже, у визначенні цінності працівника для підприємства» [4, с. 303]. Особливої уваги варто надавати оцінюванню трудових бригад, тому що саме колективна праця в галузі сільського господарства є ключовим фактором підвищення їі результативності. Від рівня згуртованості бригад, командного духу залежить продуктивність та ефективність аграрної праці.

Висновок. Особливість управління персоналом в аграрному підприємстві повинна розкривати приховані знання персоналу, розширювати межі цих знань, змінювати відносини між людьми і тим самим збільшувати людський капітал, який сьогодні є найціннішім ресурсом аграрних організацій. Загальновідомо, що вихід сільськогосподарського підприємства на позиції лідера в конкурентній боротьбі можливий лише за умови становлення на інноваційний шлях розвитку. Водночас із практичним застосуванням соціально-економічних резервів ефективного використання робочої сили це матиме позитивний вплив не лише на формування та використання трудових ресурсів, а й підвищить рівень прибутковості підприємств аграрного сектора.

$345 \mathrm{c}$.

5. Лукашевич В. М. Економіка праці та соціально-трудові відносини: Навч. пос. / В. М. Лукашевич. - Львів : Новий світ - 2000, 2004. - 248 с.

6. Макконелл К. Р., Брю С. Л. Э Экономика: принципы, проблемы и політика / Пер. с англ. 11-е изд. - К. : Хагар-Демос, 1993. - 785 с.

7. Храмов В. О., Бовтрук А. П. Основи управління персоналом: навч.-метод. пос. - К. : МАУП, 2001. - $112 \mathrm{c}$.

8. Masloy A. Motivation fund personality. - N.Y., 1970. 